\title{
Mineralization and mobilization of biosolids phosphorus in soil: A concise review
}

\author{
Abubakar Musa Ahmad ${ }^{1}$, Adamu Yunusa Ugya ${ }^{2 *}$, Habib Adamu Isah², Tijjani Sabiu Imam ${ }^{3}$ \\ ${ }^{1}$ Department of Biochemistry, Kaduna State University, Kaduna, Nigeria \\ ${ }^{2}$ Department of Environmental Management, Kaduna State University, Kaduna, Nigeria \\ ${ }^{3}$ Department of Biological Sciences, Bayero University Kano, Kano State, Nigeria
}

\begin{tabular}{l}
\hline ARTICLE INFO \\
\hline Article history: \\
Received on: June 03, 2018 \\
Accepted on: February 08, 2019 \\
Available online: September 10, 2019 \\
\hline
\end{tabular}

\section{Key words:}

Phosphorus fraction, biochar, sludge pyrolysis, agricultural lands, nitrogen

\begin{abstract}
Biosolids are the product of wastewater or municipal solid waste collected through sewerage treatment; the processes of obtaining the biosolids involve various treatment processes, which include digestion, thermal stabilization, thickening, dewatering, and drying, in order to obtain free pathogen granules. These processes undergone by wastewater in the treatment plant ultimately clean the wastewater and remove the solids which are further treated to an acceptable standard for beneficial soil amendments. The application of biosolids are considered to improve soil organic matter, moisture content, and provided essential nutrients, such as nitrogen and phosphorus in arable land as potential plant nutrients supplements for crop optimum yield. Incubation studies on the biosolids-amended soils have shown significant increases in soil phosphorus content being released as plant available $\mathrm{P}$ in the soil, and therefore could be a good source of phosphorus in deficient native phosphorus soil. Field-scale experiments on wheat are grown with sewage sludge have also shown yield production comparable to mineral fertilizer-treated soils. This review is thereby aimed at explaining the concept behind the mineralization and mobilization of biosolids phosphorus in soil. In this review paper, an overview of the method of preparations, origin, and sources, its application in agriculture and the environment, chemical composition, the environmental risk, soil amendments potentials of the biosolid sand regulatory, and global perspective of sewage sludge disposal all are reviewed. From the review, it was concluded that mineralization and mobilization of biosolids phosphorus in soil have beneficial input to both environment and soil nutrient amendment. It is thereby recommended that more research studies should be carried out on the mineralization and mobilization of another essential element, such as nitrogen and biochar although more research should be done with respect to mineralization and mobilization of biosolids phosphorus in soil.
\end{abstract}

\section{INTRODUCTION}

Biosolids are semi-solid (sewage sludge) which are generated as a result of wastewater treatment processes as represented by Figure 1 This process involves various treatment steps, including digestion, thermal lime stabilization, thickening, dewatering, and drying, in order to achieve about $99 \%-100 \%$ pathogen free granules (Fig. 1). Raw sludge is transferred to a primary or a series of settling tanks to enable the separation of solid particulates from the water fraction; the primary sludge is further transferred to

*Corresponding Author

Adamu Yunusa Ugya, Department of Environmental Management,

Kaduna State University, Kaduna, Nigeria.

E-mail:ugya88@kasu.edu.ng either aerobic or anaerobic digester where organic materials are broken down to gas or incorporated into cellular biomass [1-3]. Digested sludge is then passed into the secondary digester in the presence of alkali for thickening and finally dewatered to obtain biosolids cake, while the liquid portion or water is further treated with chlorine before disposal into rivers [4-6]. These physical, chemical, and biological processes undergone by wastewater in the treatment plant ultimately clean the wastewater and remove the solids which are further treated to an acceptable standard for beneficial soil amendments, and hence termed Biosolids. These treated residuals are known to be useful as a soil amendment in agricultural fields, recreational parks, and even home gardens [7-9]. The application of biosolids are considered to improve soil organic matter, moisture content, and provided essential nutrients, such as nitrogen and phosphorus in arable land as the potential 
plant nutrients supplements for crop optimum yield $[3,4]$. Incubation studies on the biosolids-amended soil have shown significant increases in soil phosphorus content being released as plant available $\mathrm{P}$ in the soil, and therefore could be a good source of phosphorus in deficient native phosphorus soil. Field-scale experiments on wheat is grown with sewage sludge have also shown yield production comparable to mineral fertilizer treated soils $[10,11,2]$.

\subsection{Origin and sources of biosolids}

The main sources of biosolids are derived from municipal solid waste collected through the sewerage systems by the water companies during wastewater treatment and then using different processing methods (Fig. 1) to finally obtain the desired product. Biosolids like other sources of organic waste (manure and green compost) can be applied in the soil to provide essential plant nutrients, such as phosphorus and nitrogen [12-14]. Phytoavailability of phosphorus in soil treated with biosolids is governed by several factors, including the soil characteristics and sources of biosolids phosphorus removal [15-17]. For example, biologically nutrient phosphorus removal (BNPR) produces more plant available phosphorus in soil than the chemically derived biosolids $[5,6,10]$. Thus, different sludge treatment processes could have an impact on mineralization characteristics of the phosphorus present when applied in the soil [18]. Phosphorus in biosolids is not necessarily as labile as P in mineral fertilizers or manure as their lability is greatly influenced by the wastewater treatment process [19-21]. Thermal drying significantly reduces $\mathrm{P}$ lability compared with the conventionally produced cake. The BNPR, for example, provides phosphorus uptake by microorganisms above normal levels and as such the surplus $\mathrm{P}$ is used for cell maintenance, synthesis, and energy transport through the conversion of wastewater P to microbial biomass $\mathrm{P}$ [22].

\subsection{Classification of biosolids}

Biosolids vary in their inorganic, readily mineralizable and recalcitrant nitrogen and phosphorus contents, which is particularly dependent on the sewage sludge treatment methods of production as well as their pathogen level. They are classified either as class A or $\mathrm{B}$ digested sludge.

Class A digested sludge consist of chemically or biologically treated sludges that has a level of enterococci and thermotolerant coliforms per gram of dry matter below $1000 \mathrm{cfu} / \mathrm{g}$ and is without any detection of Salmonella spp. [23], according to the set standard of the 40 code of federal regulation part 503 biosolids rule (Table 1), established by United States Environmental

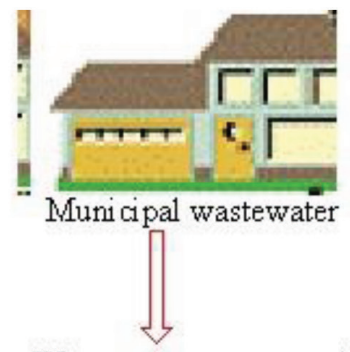

Wastewater treament plant
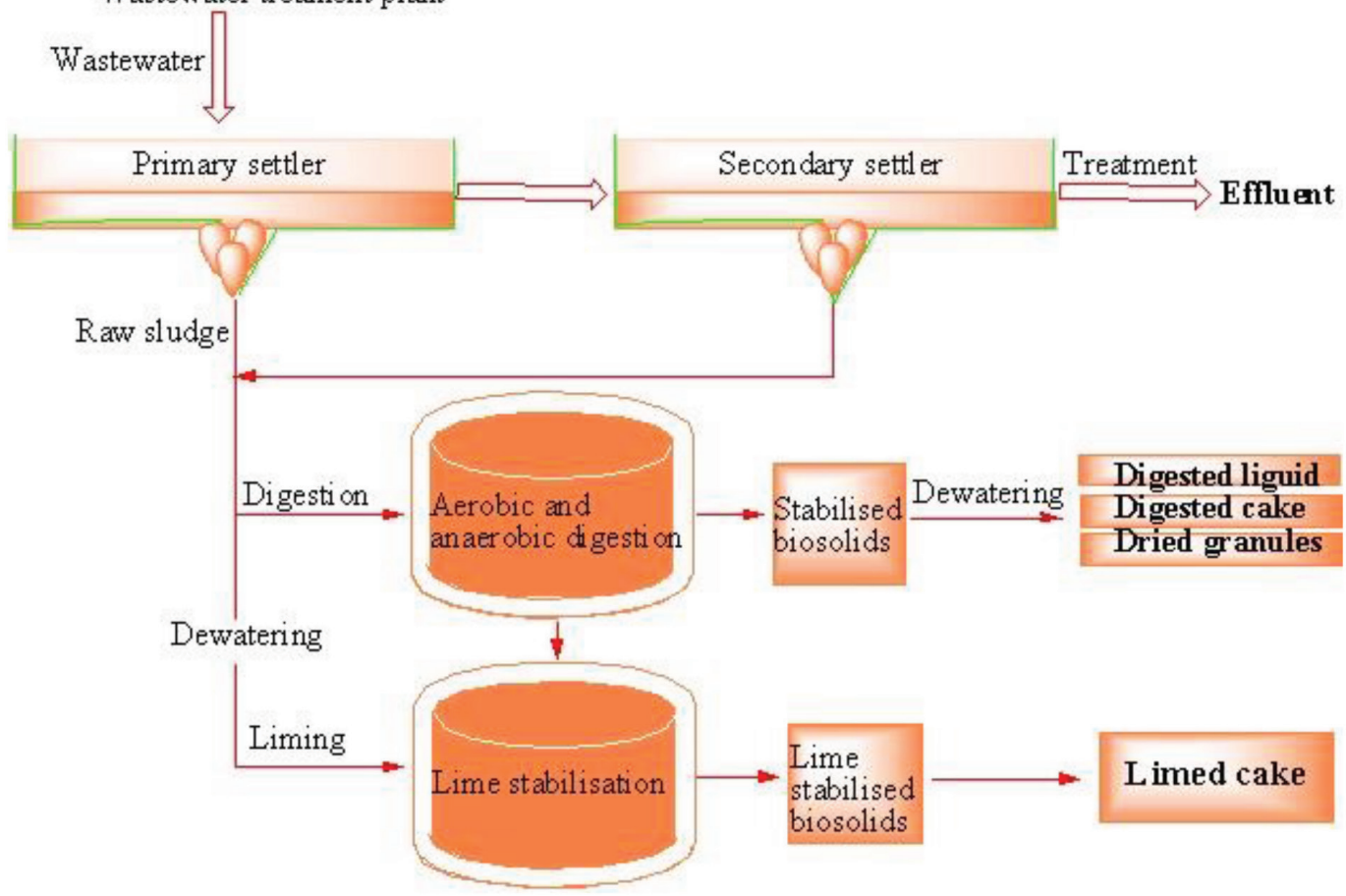

Figure 1: Production of biosolids in water industries. 
Protection Agency. Class A products are suitable as fertilizer on lawns and gardens $[23,24]$ and recommended for the application to agricultural land as it is assumed to be essentially pathogen-free [25]. In contrast, produced Class B digested sludge can contain an estimated fecal coliform density of over $1,000 \mathrm{cfu} / \mathrm{g}$ [26]. The use of Class B biosolids products are more restricted because they contain a detectable level of pathogens.

\subsection{Biosolids in agriculture and environment}

The beneficial use of biosolids in recycling to improve soil organic matter and crop nutrients in agriculture has increased since the implementation of the Sewage Sludge Directive 86/278/ EEC by the European Union in the year 1989. As a result of the implementation of directives $91 / 271 / \mathrm{EC}$, large amount of sewage sludge was generated by water companies in the United Kingdom and other European countries, such as Spain, Denmark, and France. Estimated annual production of over 9.4 million dry tones of biosolids is being generated by the European Union. While in the United States, over 7 million dry tones were generated by the wastewater treatment plants (WWTPs) each year and up to $60 \%$ were recycled on agricultural land $[27,28]$. Increase in the mineral fertilizers prices during the year 2008 (Fig. 2) in the United Kingdom have also contributed to the increased sludge production and demand for biosolids applications. Over $80 \%$ of biosolids

Table 1: Pathogen density limits.

\begin{tabular}{cc} 
Pathogens/indicator and class & Standard density limit (dry wt) \\
CLASS A & \\
Salmonellae & $<3 \mathrm{MPN} / 4 \mathrm{~g}$ of total solids \\
Fecal coliforms & $<1,000 \mathrm{MPN} / \mathrm{g}$ \\
Enteric viruses & $<1 \mathrm{PFU} / 4 \mathrm{~g}$ of total solids \\
Viable helminths ova & $<1 \mathrm{PFU} / 4 \mathrm{~g}$ of total solids \\
CLASS B & \\
Fecal coliform density & $<2000,000 \mathrm{MPN} / \mathrm{g}$ of total solids \\
\hline
\end{tabular}

MPN = most probable numbers; $\mathrm{PFU}=$ plaque forming units. are nowadays directly or indirectly used on land in England [29-31]. Even though the application of biosolids in agriculture and environment have beneficial effects, there have been several concerns about their short- and long-term effects on agricultural soil and environment due to the presence of potential contaminated substances such as heavy metals or other pathogens if not properly treated and could be dangerous and toxic to human health and the environment $[32,33]$. Nonpoint-source pollution of surface water or eutrophication by agricultural phosphorus have been a major environmental concern worldwide [34] and a significant fraction of this phosphorus mostly originated from organic waste, such as manure and biosolids used during soil amendments [35].

Biosolids like other sources of organic fertilizer can provide essential (nitrogen and phosphorus) nutrients to agricultural soil. There are different nutrient compositions of mainly phosphorus and nitrogen along with few micronutrients, such as iron, copper, and zinc [36]. The nitrogen and phosphorus contents are typically in the ranges of $2.8 \%-3.8 \%$ and $1.2 \%-3.0 \%$, respectively [36]. The higher the quantity of available nitrogen and phosphorus is found in the dry digested cake (Table 2). However, there is a large variability in the phosphorus contents present in biosolids, depending on the treatments methods [37-39] and the relative effectiveness of biosolids-P is $50 \%$ compared to soluble fertilizer $\mathrm{P}$ according to the recommendations in both United Kingdom and the United States. Potassium content of biosolids is very low $(0.15 \%-0.40 \%)$ because most of the compounds are water soluble and remains in the sewage effluent or aqueous fraction during sludge dewatering [3].

\subsection{Chemical form}

The chemical form of phosphorus in biosolids influences the environmental chemistry and plant availability of soil P [40-42]. Most of the biosolids-P produced through chemical treatment of wastewater during phosphorus removal is associated with inorganic iron bound (Fe-bound) or aluminum bound (Al-bound) phosphates [10]. In a greenhouse study [15], the effects of biosolids amendments on $\mathrm{P}$ availability in two sandy pasture soils with medium and very

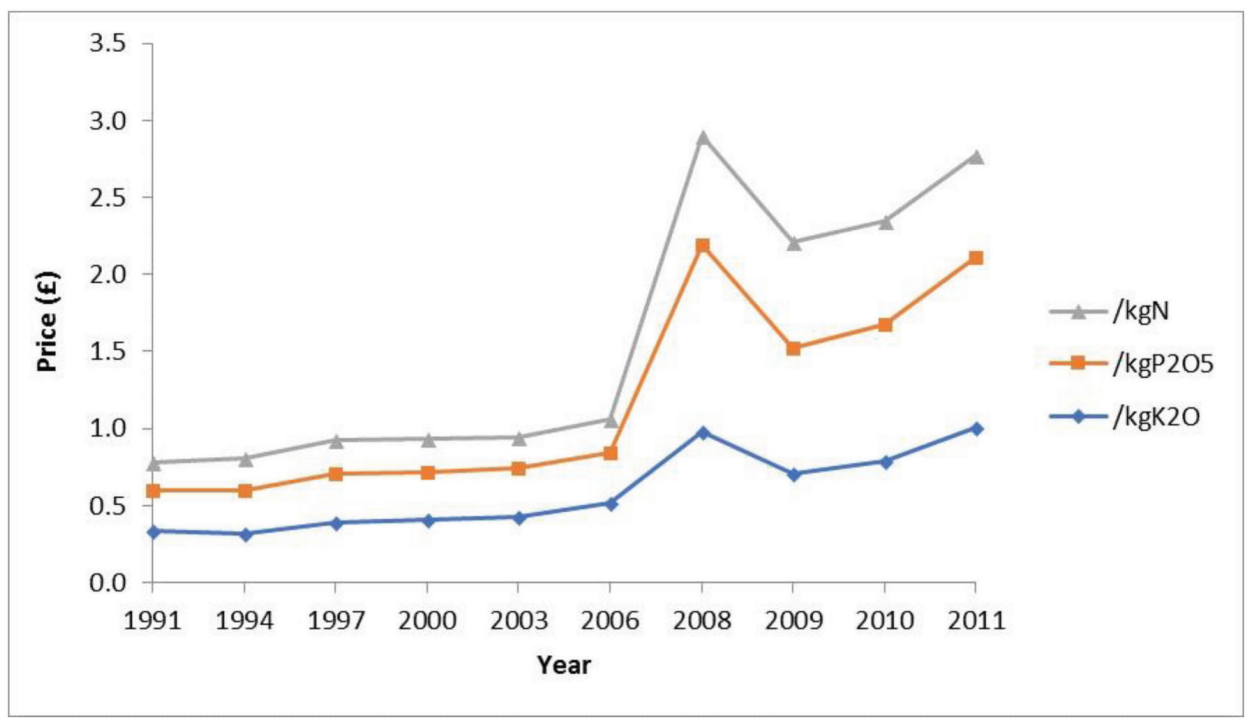

Figure 2: UK Fertilizer prices (1991-2011) nutrients composition of biosolids. 
Table 2: A typical nitrogen and phosphorus content of sewage sludges.

\begin{tabular}{cccccc} 
Sludge type & Dry matter $(\%)$ & Total nitrogen & Total phosphorus & Available $\mathbf{N}$ & Available P \\
Liquid undigested $\left(\mathrm{kg} / \mathrm{m}^{3}\right)$ & 5 & 1.8 & 0.6 & 0.6 & 0.3 \\
Liquid digested $\left(\mathrm{kg} / \mathrm{m}^{3}\right)$ & 4 & 2.0 & 0.7 & 1.2 & 0.3 \\
Undigested cake $(\mathrm{kg} / \mathrm{t})$ & 25 & 7.5 & 2.8 & 1.5 & 1.4 \\
Digested cake $(\mathrm{kg} / \mathrm{t})$ & 25 & 7.5 & 3.9 & 1.1 & 2.0 \\
\hline
\end{tabular}

high native $\mathrm{P}$ content, respectively, was evaluated, 4 months after treatment, the grown cropping season bahiagrass yields did not show significance with P-sources or application rates, particularly in the very high native $\mathrm{P}$ soil. This was mainly due to the excessive high soil-P with high $\mathrm{P}$ retention capacity, as a result, it has masked the effect of biosolids added phosphorus [43-45].

\subsection{Microbiology}

Soil organic carbon is the main source of energy for soil microorganisms [46]. Microorganisms in the soil are able to obtain available phosphorus upon hydrolysis of organic P catalyzed by soil extracellular phosphatase enzymes. Extracellular phosphatases are those enzymes released into soil from active or non-proliferating cells, such as spores, cysts, seeds, and endospores that becomes attached to dead cells or cell debris and absorbed to clay and humic colloids that play important role in catalyzing the organic phosphorus hydrolysis reaction to release inorganic phosphorus [47]. Organic matter content in biosolids would also provide energy which could contribute toward sustaining biological activity during nutrient mineralization in soil [47]. Therefore, understanding of biological processes, such as microbial biomass carbon and enzyme activities during the mineralization of organic matter and nutrient turnover, is very important [47]. Microbial biomass is those cells of living microorganisms notably, bacteria, actinomycetes, and fungi that play vital roles in nutrient cycling and soil aggregation [48]. Biomass also functions as a sink for nutrients, such as phosphorus and nitrogen, under conditions of net immobilization depending on the state of the whole system. During a 4-year study of crop rotation system with sunflower, winter wheat, lentil, and winter wheat as the grown crops, when matured composts of vegetal and animal sources were consecutively added as a source of organic matter in soil, microbial biomass carbon was observed to increase with increase in soil total organic carbon even though other factors, such as soil moisture, $\mathrm{pH}$, and temperature, could have an effect on this relationship $[49,50]$.

Microbial phosphorus immobilization can affect $\mathrm{P}$ availability by removing inorganic $\mathrm{P}$ from soil solution particularly when soluble carbon is available for microbial growth. Phosphorus in soil interacts with other essential nutrients, such as carbon and nitrogen, in regulating biological processes and as such, the ratio of $\mathrm{C}: \mathrm{N}: \mathrm{P}$ is an important indicator for estimating carbon and nutrient fluxes during the global circulation models. Simple index measurement of the ratio of microbial biomass carbon to total organic carbon content (Cmic/TOC) is used as an indicator of carbon availability to microorganisms, conversion efficiency, losses of carbon, and carbon stabilization of soil [51]. Extracellular enzymatic activity of phosphatase showed a positive correlation with microbial biomass carbon, and the available phosphorus results were also correlated with the alkaline phosphatase activity in the matured compost treated soil [52]. The soil enzymes secreted by the microorganisms, to initially cleave or hydrolyze organic matter into smaller molecules are also potential indicators of soil quality as they play role in soil management, providing information on the biochemical processes occurring in soil [5355]. Phosphatase enzymes activities, for example, are important during mineralization of organic phosphorus in soil [54].

\subsection{Regulation and global perspectives}

Disposal of sewage sludges to sea was banned by the European Union (EU) under the water treatment directive 91/271/EEC in the year 1998 [53]. This has resulted in the generation of a large amount of sewage sludges by water companies in the United Kingdom with over 9.4 million tones of dry weight produced annually in the European Union [53]. The implementation of directives and other legislative measures in the European Union concerning collection, treatment, and discharge of wastewater as well as advancement in the technological upgrading of WWTPs have caused more sludge production and even expected to increase up to 13 million tones in all EU member states by 2020 [42]. Safe disposal of biosolids is vital, as it is a major environmental concern throughout the world which presents a major challenge in the wastewater management industries [56,57]. In the United Kingdom (UK), biosolids land application and recycling is considered the best practicable options. About $80 \%$ of sludges go to land in the UK, while in the USA up to $60 \%$ biosolids are mostly recycled to agricultural soils to supply farmers with the economic alternative of chemical fertilizers.

Other disposal options include landfilling and incineration [58].

\subsection{Environmental risks}

Even though dewatered end products of the wastewater treatment companies are highly nutrient enriched (nitrogen and phosphorus) and amenable to use as agricultural fertilizer or as mine waste covers, they are recognized as repositories of organic pollutants and heavy metals [59]. Thus, there are public concerns of biosolids application with regards to these potentially toxic elements or organic compounds effects over time. For example, the application of biosolids to agricultural soils in excess of crop needs, when an N-based approach is used to determine land application rates, would results in the build-up of soil $\mathrm{P}$, which is also amongst the direct similarity with manure and that pose significant risk to surface and groundwater during erosion and surface run-off in soil [60]. However, environmental risk of biosolids application is minimal to both humans and environment (microorganisms) if properly managed according to the strict measures and regulations by the European Union directives. Moreover, compared to manure (dairy cattle slurry), biosolids do not pose a greater risk in terms of losses along the runoff pathway in grassland soil [61]. 


\subsection{Quantity of biosolids application in agricultural soils}

There are major concerns, particularly regarding the long-term effects of biosolids application in agriculture and consequence on the soil and water quality. Biosolids are mostly applied to soil to meet nitrogen requirements in most agronomic crops with little regard to the phosphorus content, and this can result in the buildup of phosphorus in the soil $[62,63]$. In order to mitigate soil phosphorus, build-up, several State and Federal agencies, such as Ministry of Agriculture, Fisheries and Food and Department for Environment, Food and Rural Affairs, have recommended P-based nutrient management strategies depending on characteristics of native $\mathrm{P}$ of soils and other factors, such as $\mathrm{pH}$, soil texture, organic matter, soil moisture content, and microbial activity [64].

\subsection{Biosolids in soil}

Application of biosolids to soil provides dissolved organic matter source, that causes initial degradation of decomposable fractions, accompanied by increased microbial activity in the sludge-amended soil which may lead to a priming effect that can result in concomitant decomposition of native soil organic carbon [65]. Biosolids induced positive priming effects increases the decomposition of native soil carbon as such there is an increase in the energy sources of microbial populations and subsequent increase in microbial activity in the soil [66]. Negative priming effects where decomposition of the native carbon in soil is reduced upon addition of organic residuals, such as biosolids or biochar, would instead promote the immobilization of carbon [66]. Reactions of soil, such as sorption-desorption, precipitation, or metal speciation, play critical roles in nutrient availability which often depends on the soil $\mathrm{pH}$ as one of the key factors [67]. Residuals from biosolids have a significant influence on solubility and speciation of soil nutrients. Buffering capacity which is the ability of soil solution to resist change in concentration of phosphorus when phosphorus is removed during plant uptake or added as fertilizer $\mathrm{P}$ and other amendments, such as manure and biosolids, can be an important soil characteristics controlling relationship of solid phase $\mathrm{P}$ and it is concentration in soil solution $[68,69]$. For example, temporary induced increases or decreases of soil $\mathrm{pH}$ upon amendments could be restored after sometimes, perhaps due to soil buffering capacity [70,71]. The solubility of iron bound biosolids-P was shown to be lower in biosolids-amended soils in terms of the P release or phytoavailability, compared to the thermally lime-stabilized biosolids or poultry litter [71].

\section{CHEMICAL AND PHYSICAL PARAMETERS INFLUENCING BIOSOLIDS MINERALISATION IN SOIL}

\section{1. $\mathrm{pH}$}

Soil $\mathrm{pH}$ has been an important factor affecting the bioavailability of phosphorus for plant uptake.

In treated sludge, $\mathrm{pH}$ is a key factor toward controlling the phosphorus chemistry [72]. Application of biosolids in soil affected $\mathrm{pH}$ by either increasing or decreasing it depending on the initial soil $\mathrm{pH}$ and application rates. As a result, it affects solubility and availability of nutrients and the soil microbial activities [73]. At extreme $\mathrm{pH}(>10$ or $<4)$, microbial activity is inhibited and that can affect the mineralization of $\mathrm{P}$ in soil [74]. The dissolution and solution equilibrium reactions for the availability of inorganic phosphate in soil is largely achieved based on soil $\mathrm{pH}$, phosphate minerals (iron and calcium), and their organic matter content [73]. For example, soluble phosphorus in oxides and hydroxides of aluminum or iron in the soil increases with $\mathrm{pH}$ levels up to about 6.5 and then, decreases significantly above the neutral $\mathrm{pH}$ or in high calcium phosphate compounds soils [74]. Dihydrogen phosphate ion (H2PO4) generally dominates at $\mathrm{pH}$ ranges between 2.2 and 7.2. While at 7.2-12.4 $\mathrm{pH}$ ranges, monohydrogen phosphate ion $\left(\mathrm{HPO}^{2-}\right)$ are the dominant species. In calcareous soil, calcium $(\mathrm{CaCO} 3)$ will react with phosphate (HPO42-) to precipitate phosphate ion [73]. The optimum $\mathrm{pH}$ for $\mathrm{P}$ availability to crops in the soil is between 6 and 7 [75]. Lowering soil $\mathrm{pH}$ (4.5-5.1) causes decreased soil microbial activities and can lead to subsequent changes in the substrate utilization $[76,77]$.

\subsection{Organic matter}

The organic matter content presence in soil controls the dynamics of phosphorus in soil. It plays a vital role, as it affects many important soil properties [78]. For example, decomposing organic matter releases an acid that increases the solubility of calcium sulfate which causes an increase in the amount of available P. Organic matter forms two complex matrices associated with particles and other nutrients in the soil, mostly referred as coarse and fine fractions of soil organic matter [78,79]. The coarse fraction of soil organic matter (CF-SOM) is that organic material $(\mathrm{CF}>$ $0.4 \mathrm{~mm}$ ) composed of un-decayed plant and animal residues and recognized as highly labile material due to fast rates of organic matter breakdown [78] In contrast, fine fraction soil organic matter (FF-SOM $<0.4 \mathrm{~mm}$ ) is considered to be more stabilize and slowly decomposing pool of soil organic material [79]. Application of organic residuals, such as manure, green compost, or biosolids, as sources of organic matter to improve soil physical, chemical, and biochemical properties has been practiced for a long time [80]. The addition of an organic substrate generally results in an increase in the size and activity of the soil microbial community as well as activities of extracellular soil enzymes [81]. The residuals from biosolids originate mainly from human feces and bacterial cells during primary and secondary sludge treatments, respectively [82]. Their organic carbon (C) ranges mostly between $20 \%$ and $50 \%$ and overall organic fraction of biosolids consist of a mixture of fats, carbohydrates, protein, lignin, amino acids, cellulose, sugars, humic materials, and fatty acids [82]. There were increases in the concentration of dissolved organic matter in soil solution following biosolids application, which subsequently decreases over time as the added biosolids organic matter decomposes [83]. Organic matter and $\mathrm{pH}$ in soil stimulate microbial biomass growth and this is beneficial to the majority of microbes as it provides more surface area in addition to carbon or energy sources for microbial activities such as effective nutrients degradation and mineralization [84].

\subsection{Moisture content}

Soil moisture is amongst one of the key controlling factors for the available phosphorus in soil. The drying and re-wetting of arable and grassland soils, therefore, have an effect on the release of biosolids-P [85]. The decrease in microbial biomass carbon with an increase in 
extractable phosphorus in an air-dried soil during the drying cycle was shown [85]. However, a constant microbial biomass carbon was observed with seasonal changes in microbial $\mathrm{P}$ content and organic $\mathrm{P}$ mineralization during spring and then $\mathrm{P}$ immobilization in the early winter months [84]. Under optimal soil moisture and temperature, a significant immobilization-remobilization sequence occurs upon addition of organic materials to soils and the pattern and dynamic of phosphorus turn over in such situation depend on the substrate, the microbial biomass (size, activity and composition), soil properties, and community structure of soil [86]. Immobilization of $\mathrm{P}$ in microorganisms also increases with an increase in the proportion of soluble carbon in the added substrates (biosolids) and the initial size of the microbial biomass [87].

\subsection{Temperature}

The solubility of phosphate ions in soil is also governed by temperature in addition to moisture content. The impacts of temperature on biosolids-treated soil phosphorus release and mineralization are minimal because phosphorus is typically immobile in most soil [36]. During a 90 days' soil incubation study by Silveira and O'Connor [88], it shows that an increase in the temperature from $20^{\circ} \mathrm{C}$ to $32^{\circ} \mathrm{C}$ has caused increased soil $\mathrm{P}$ retention which results in the low release of phosphorus into the soil solution. Even though the distribution of phosphorus amongst various fractions were not significantly affected by the changes in temperature. Treatments of soil with biosolids play little role in terms of differences of soil biosolids-P release or concentrations particularly in a high phosphorus content soil, or in those soil with high affinity to retain $\mathrm{P}$, as it is being easily masked by P-enriched soils at the surfaces [89].

\section{MINERALIZATION OF BIOSOLIDS PHOSPHORUS IN SOIL}

Mineralization of $\mathrm{P}$ is the process by which soil microbes break down soluble and insoluble P nutrients present in organic matter through extracellular phosphatase enzymes secretion that becomes available to both plant and microorganisms [90]. Phosphorus mineralized in the soil after organic sources input of manure, such as cow dung or biosolids, is an important factor in determining overall $\mathrm{P}$ availability in soil [91]. Soil native $\mathrm{P}$ increase, during biosolids-P mineralization, may lead to modification in the distribution of $\mathrm{P}$ in various pools, and can subsequently increase the soil total P over time [92]. About $90 \%$ of applied phosphorus from biosolids in soil is not taken up by the plants. Rather, it is retained (locked-up) as insoluble or fixed $\mathrm{P}$ so that residual $\mathrm{P}$ can be used by subsequent growing crops [93].

\subsection{Phosphorus cycle}

Phosphorus is an essential element and its availability contributes to controlling some aspects of global biogeochemical processes, such as soil genesis [94]. Phosphorus cycle in the soil are generally controlled by inorganic adsorption-desorption reactions, biologically controlled mobilization and immobilization by the microbial biomass, and the native P forms, principally, whether it is in an organic or inorganic form [95]. In natural ecosystems, phosphorus is usually a scarce resource and is efficiently being recycled; whereas, in agricultural systems, $\mathrm{P}$ is removed in crops or animal products. Figure 3 shows phosphorus cycling in soil [94].

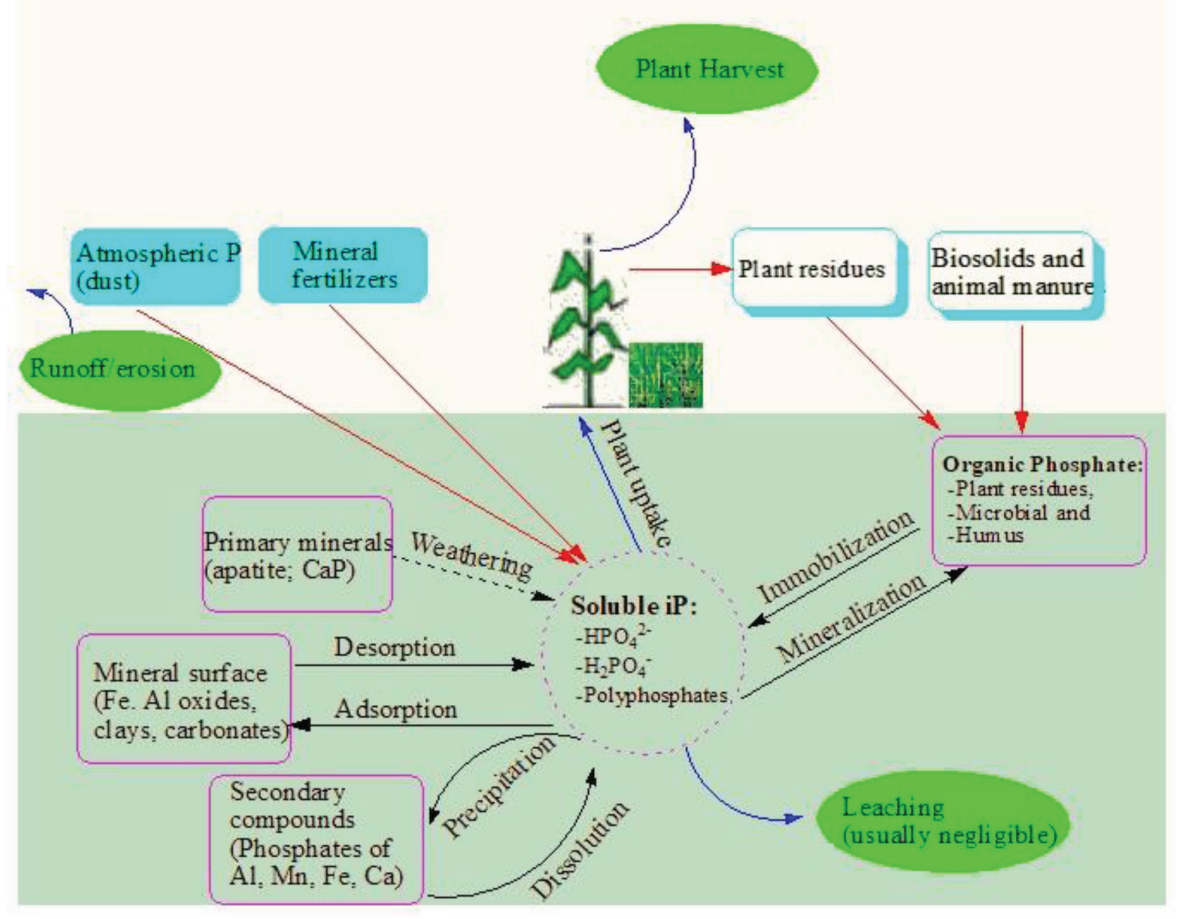

Figure 3: Phosphorus cycle in soil. 


\section{CONCLUSION}

Phosphorus nutrients in soil organic matter are mostly present in the organic form. They are converted to inorganic forms through the process of mineralization in order to become available to crops. Phosphorus mineralization in soil is simply the release of orthophosphate during the decomposition of phosphorus nutrient containing organic materials, facilitated by extracellular phosphatase enzymes released by the soil microbes. Soil organic $\mathrm{P}$ is derived from the combination of plant, animal, and microbial residues and provides important $\mathrm{P}$ turnover during mineralization both in the organic and microbial biomass pools that form a vital component of P cycling in soil plant systems [96]. Mineralization of phosphorus in soil is partly regulated by the carbon phosphorus ratio (C:P) of substrates [97]. Carbon-phosphorus ratio (C:P) greater than 100, for example, indicates high requirements of $\mathrm{P}$ (1.5\%-2.5\% of dry weight) by soil microorganisms and as such, $\mathrm{P}$ would rather be immobilized by microbes. Microbes, therefore, compete with plants for available $\mathrm{P}$ in soil. Mineralization of phosphorus from microorganisms is also affected by the soil texture [98]. Immobilization involves the uptake of the organic forms of phosphorus into the microbial biomass and it is a reaction catalyzed by those active microbial biomass fractions in the soil in order to acquire energy [99]. Microbial immobilization of $\mathrm{P}$ is a vital process that provides an important source of available $\mathrm{P}$, as it can often contain up to $20 \%-30 \%$ of the total soil organic $\mathrm{P}$ pool, which is even significantly higher compared to carbon $(1 \%-2 \%)$ and nitrogen $(2 \%-10 \%)$ proportions in the soil microbes [100]. Thus, biomass in this situation acts as a labile pool of $\mathrm{P}$ which is protected from fixation but is rather plant-available during biomass turnover [101]. Both mineralization and immobilization are depicted in Figures 1-3. Microbial P immobilization makes soil P temporarily unavailable to plants at some points but eventually becomes available upon complete microbial decomposition due to the simultaneous mineralization-immobilization processes during phosphorus turnover $[102,103]$. Due to the fact that, mineralization of soil organic phosphate pools is achieved through extracellular phosphatase enzymes activities, several factors, such as organic materials ratio ( $\mathrm{C}: \mathrm{N}: \mathrm{P}), \mathrm{pH}$, moisture, and fertilizer $\mathrm{P}$ amendments affects phosphatase activities which could subsequently have effects on the organic $\mathrm{P}$ mineralization [104]. It is thereby recommended that more research should be done with respect to mineralization and mobilization of biosolids phosphorus in soil.

\section{REFERENCES}

1. Méndez A, Cárdenas-Aguiar E, Paz-Ferreiro J, Plaza C, Gascó G. The effect of sewage sludge biochar on peat-based growing media. Biol Agric Hortic 2017;33:40-51.

2. Liu W, Huo R, Xu J, Liang S, Li J, Zhao T, Wang S. Effects of biochar on nitrogen transformation and heavy metals in sludge composting. Bioresour Technol 2017;235:43-9.

3. Jorge P, Aurora N, Ana M, Matthew PJA, Gabriel G. Biochar from biosolids pyrolysis: a review. Int J Environ Res Public Health 2018;15:956.

4. Awasthi MK, Wang M, Chen H, Wang Q, Zhao J, Ren X, et al. Heterogeneity of biochar amendment to improve the carbon and nitrogen sequestration through reducing the greenhouse gases emissions during sewage sludge composting. Bioresour Technol 2017;224:428-38.
5. Torri SI, Corr^ea RS, Renella G. Biosolid application to agricultural land-a contribution to global phosphorus recycle: a review. Pedosphere 2017;27(1):1-16.

6. Ross JJ, Zitomer DH, Miller TR, Weirich CA, MacNamara PJ. Emerging investigator series: pyrolysis removes common microconstituents triclocarban, triclosan and nonylphenol from biosolids. Environ Sci Water Res Technol 2016;2:282-9.

7. Roberts DA, Cole AJ, Whelan A, de Nys R, Paul NA. Slow pyrolysis enhances the recovery and reuse of phosphorus and reduces metal leaching from biosolids. Waste Manag 2017;64:133-9.

8. Peltz CD, Harley A. Biochar application for abandoned mine land reclamation. In: Agricultural and environmental applications of biochar: advances and barriers, pp 325-40, 2016.

9. Paneque M, de la Rosa JM, Kern J, Reza MT, Knicker H. Hydrothermal carbonization and pyrolysis of sewage sludges: what happens to carbon and nitrogen? J Anal Appl Pyrolysis 2017;128:314-23.

10. Page-Dumroese DS, Robichaud PR, Brown RE, Tirocke JM. Water repellency of two forest soils after biochar addition. Trans ASABE 2015;58(2):335-42.

11. Olmo M, Lozano AM, Barrón V, Villar R. Spatial heterogeneity of soil biochar content affects soil quality and wheat growth and yield. Sci Total Environ 2016;562:690-700.

12. Malinska K, Golanska M, Caceres R, Rorat A, Weisser P, Slezak E. Biochar amendment for integrated composting and vermicomposting of sewage sludge - the effect of biochar on the activity of Eisenia fetida and the obtained vermicompost. Bioresour Technol 2017;225:206-14.

13. Ippolito JA, Berry CM, Strawn DG, Novak JM, Levine J, Harley A. Biochars reduce mine land soil bioavailable metals. JEQ 2017;46(2):411-9.

14. Hoffman TC, Zitomer DH, McNamara PJ. Pyrolysis of wastewater biosolids significantly reduces estrogenicity. J Hazard Mater 2016;317:579-84.

15. Gonzaga MIS, Mackowiak CL, Comerford NB, Moline EFV, Shirley JP, Guimaraes DV. Pyrolysis methods impact biosolids-derived biochar composition, maize growth and nutrition. Soil Till Res 2017; 165:59-65.

16. Awasthi MK, Zhang Z, Wang Q, Shen F, Li R, Ren X, et al. New insight with the effects of biochar amendment on bacterial diversity as indicators of biomarkers support the thermophilic phase during sewage sludge composting. Bioresour Technol 2017;238:589-601.

17. Álvarez ML, Gascó G, Plaza C, Paz-Ferreiro J, MéndezA. Hydrochars from biosolids and urban wastes as substitute materials for peat. Land Degrad Dev 2017;28:2268-76.

18. Bol R, Julich D, Brödlin D, Siemens J, Kaiser K, Dippold MA, et al. Dissolved and colloidal phosphorous fluxes in forest ecosystemsan almost blind spot in ecosystem research. J Plant Nutr Soil Sci 2016;179(4):425-38.

19. Fujita K, Kunito T, Moro H. Microbial resource allocation for phosphatase synthesis reflects the availability of inorganic phosphorus across various soils. J Biogeochem 2017;136:325-39.

20. Moro H, Kunito T, Sato T. Assessment of phosphorus bioavailability in cultivated Andisols from a longterm fertilization field experiment using chemical extractions and soil enzyme activities. Arch Agron Soil Sci 2015;61:1107-23.

21. Page-Dumroese DS, Ott MR, Strawn DG, Tirocke JM. Using organic amendments to restore soil physical and chemical properties of a mine site in northeastern Oregon, USA. Appl Eng Agric 2018;34(1):43-55.

22. Spohn M, Treichel NS, Cormann M, Schloter M, Fischer D. Distribution of phosphatase activity and various bacterial phyla in the rhizosphere of Hordeum vulgare L. depending on P availability. Soil Biol Biochem 2015;89:44-51.

23. Takashi K, Naomi H, Yasunori M, Hirotaka S, Hitoshi M. Changes in phosphorus fractions caused by increased microbial activity in forest soil in a short-term incubation study. Chem Spec Bioavailab 2018;30(1):9-13. 
24. Boyce RL, Schaberg PG, Hawley GJ, Halman JM, Murakami PF. Effects of soil calcium and aluminum on the physiology of balsam fir and red spruce saplings in northern New Engl Trees 2013;27:1657-67.

25. Zhang Y, Chen P, Liu S, Peng P, Min M, Cheng Y, et al. Effects of feedstock characteristics on microwave-assisted pyrolysis - a review. Bioresour Technol 2017;230:143-51.

26. Zebarth BJ, Forge TA, Goyer C, Brin LD. Effect of soil acidification on nitrification in soil. Can J Soil Sci 2015;95:359-63.

27. Sharifi M, Cheema M, McVicar K, LeBlanc L, Fillmore S. Evaluation of liming properties and potassium bioavailability of three Atlantic Canada wood ash sources. Can J Plant Sci 2013;93:1209-16.

28. Reid C, Watmough SA. Evaluating the effects of liming and wood-ash treatment on forest ecosystems through systematic meta-analysis. Can J For Res 2014;44:867-85.

29. Pugliese S, Jones T, Preston MD, Hazlett P, Tran H, Basiliko N. Wood ash as a forest soil amendment: the role of boiler and soil type on soil property response. Can J Soil Sci 2014;94:621-34.

30. Moore J-D, Ouimet R, Long RP, Bukaveckas PA. Ecological benefits and risks arising from liming sugar maple dominated forests in northeastern North America. Environ Rev 2015;23:66-77.

31. Merino A, Beatriz O, Hidalgo C, Etchevers JD, Balboa MA. Characterization of the organic matter in wood ash from biomass power plants in relation to the potential use as amendments in agriculture. Land Degrad Develop 2017:2166-75.

32. Long RP, Bailey SW, Horsley SB, Hall TJ, Swistock BR, DeWalle DR. Long-term effects of forest liming on soil, soil leachate, and foliage chemistry in northern Pennsylvania. Soil Sci Soc Am J 2015;79:122336.

33. Capodaglio AG, Callegari A, Dondi D. Microwave-induced pyrolysis for production of sustainable biodiesel from waste sludges. Waste Biomass Valoriz 2016;7:703-9.

34. Raboni M, Viotti P, Capodaglio AG. A comprehensive analysis of the current and future role of biofuels for transport in the European Union (EU). Ambiente \& Água — an interdisciplinary. J Appl Sci 2015;10:921.

35. Budarin VL, Shuttleworth PL, De bruyn M, Farmer TJ, Gronnow MJ, Pfaltzgraff L, et al. The potential of microwave technology for the recovery, synthesis and manufacturing of chemicals from bio-wastes. Catal Today 2015;239:80-9.

36. Masek O, Budarin V, Gronnow M, Crombie W, Brownsort P, Fitzpatrick E, et al. Microwave and slow pyrolysis biocharcomparison of physical and functional properties. J Anal Appl Pyrolysis 2013;100:41-8.

37. Brodie G, Destefani R, Schneider PA, Airey L, Jacob MV. Dielectric properties of sewage biosolids: measurement and modeling. J Microw Power Electromagn Energy 2014;48:147-57.

38. Liu T, Liu B, Zhang W. Nutrients and heavy metals in biochar produced by sewage sludge pyrolysis: its application in soil amendment. Pol J Environ Stud 2014;23:271-5.

39. Zielinska A, Oleszczuk P, Charmas B, Skubiszewska-Zieba J, Pasieczna-Patkowska Z. Effect of sewage sludge properties on the biochar characteristic. J Anal Appl Pyrolysis 2015;112:201-13.

40. Anawar HM, Akter F, Solaiman ZM, Strezov V. Biochar: an emerging panacea for remediation of soil contaminants from mining, industry and sewage wastes. Pedosphere 2015;25(5):654-65.

41. Capodaglio AG. High-energy oxidation process: an efficient alternative for wastewater organic contaminants removal. Clean Technol Environ. Policy 2017;19:1995-2006.

42. Capodaglio AG, Cecconet D, Molognoni D. An integrated mathematical model of microbial fuel cells processes. Bioelectrochem Microbiol Aspects 2017;5:73.

43. Cassidy R, Doody DG, Watson CJ. Impact of legacy soil phosphorus on losses in drainage and overland flow from grazed grassland. Soils Sci Tot Environ 2017;575:474-84.

44. Cecconet D, Devecseri M, Callegari A, Capodaglio AG. Effects of process operating conditions on the autotrophic denitrification of nitrate-contaminated groundwater using bioelectrochemical systems Sci Total Environ 2017;613-4, 663-71.

45. Cordell D, Neset T-S. Phosphorus vulnerability: a qualitative framework for assessing the vulnerability of national and regional food systems to the multidimensional stressors of phosphorus scarcity Glob. Environ Change 2014;24:108-22.

46. Daly K, Styles D, Lalor S, Wall D. Phosphorus sorption, supply potential and availability in soils with contrasting parent material and soil chemical properties Eur J Soil Sci 2015;66:792-801.

47. Dodd RJ, Sharpley AN. Conservation practice effectiveness and adoption unintended consequences and implications for sustainable phosphorus management. Nutr Cycles Agroecosyst 2016;104:373-92.

48. Zhang Y, Collins AL, Murdoch N, Lee D, Naden PS. Cross sector contributions to river pollution in England and wales: updating waterbody scale information to support policy delivery for the Water framework directive. Environ Sci Policy 2014;42:16-32.

49. Withers PJA, van Dijk KC, Neset T-SS, Nesme T, Oenema O, Rubæk $\mathrm{GH}$, et al. Stewardship to tackle global phosphorus inefficiency: the case of Europe. Ambio 2015;44:S193-206.

50. Withers PJA, Sylvester-Bradley R, Jones DL, Healey JR, Talboys PJ. Feed the crop not the soil: rethinking phosphorus management in the food chain. Environ Sci Technol 2014;48:6523-30.

51. Ugya AY, Imam TS. Temporal heavy metals variation in vegetables sampled at kasuwan mata, kaduna metropolis, Nigeria. Malay J Sci 2017;36(2):63-73.

52. Trojanowicz M, Bojanowska-Czajka A, Capodaglio AG. Can radiation chemistry supply a highly efficient AO (R) P process for organics removal from drinking and waste water? A review. Environ Sci Pollut Res 2017;24:20187-208

53. Tan X, Liu Y, Zeng G, Wang X, Hua X, Gu Y, et al. Application of biochar for the removal of pollutants from aqueous solutions. Chemosphere 2015;125:70-85.

54. Shore M, Jordan P, Mellander PE, Kelly-Quinn M, Wall DP, Murphy $\mathrm{PNC}$, et al. Evaluating the critical source area concept of phosphorus loss from soils to waterbodies in agricultural catchments. Sci Tot Environ 2014;490:405-15.

55. Rajapaksha AU, Chen SS, Tsang DCW, Zhang M, Vithanage M, Mandal S, et al. Engineered/designer biochar for contaminant removal/ immobilization from soil and water: Potential and implication of biochar modification. Chemosphere 2016;148:276-91.

56. Qian K, Kumar A, Zhang H, Bellmer D, Huhnke R. Recent advances in utilization of biochar. Renew Sustain Energy Rev 2015;42:1055-64.

57. Ok YS, Chang SX, Gao B, Chung HJ. SMART biochar technology-a shifting paradigm towards advanced materials and healthcare research. Environ Technol Innov 2015;4:206-9.

58. Musolff A, Selle B, Buettner O, Opitz M, Tittel J. Unexpected release of phosphate and organic carbon to streams linked to declining nitrogen depositions Glob Change Biol 2017;23:1891-901.

59. Molognoni D, Devecseri M, Cecconet D, Capodaglio AG. Cathodic groundwater denitrification with a bioelectrochemical system. J Water Process Eng 2017;19:67-73.

60. Meng J, Feng X, Dai Z, Liu X, Wu J, Xu J. Adsorption characteristics of $\mathrm{Cu}$ (II) from aqueous solution onto biochar derived from swine manure. Environ Sci Pollut Res 2014;21:7035-46.

61. Lawrence GB, Burns DA, Riva-Murray K. A new look at liming as an approach to accelerate recovery from acidic deposition effects. Sci Tot Environ 2016;562:35-46.

62. Knight S, Morris N, Goulding K, Johnston J, Poulton P, Philpott H. Identification of critical soil phosphate (P) levels for cereal and oilseed rape crops on a range of soil types. Warwickshire: Home Grown Cereals Authority Agriculture and Horticulture Development Board); 2014. 74 p. Report No. 529.

63. King KW, Williams MR, Johnson LT, Smith DR, LaBarge GA, Fausey NR. Phosphorus availability in western Lake Erie basin drainage waters: legacy evidence across spatial scales. J Environ Qual 2104;46:466-9. 
64. Kacprzak A, Kobyłecki R, Włodarczyk R, Bis Z. The effect of fuel type on the performance of a direct carbon fuel cell with molten alkaline electrolyte. J. Power Sources 2014;255:179-86.

65. Huggins T, Wang H, Kearns J, Jenkins P, Ren ZJ. Biochar as a sustainable electrode material for electricity production in microbial fuel cells. Bioresour Technol 2014;157:114-9.

66. Doody DG, Withers PJA, Dils RM, McDowell RW, Smith V, McElarney YR, et al. Optimising land use for the delivery of catchment ecosystem services. Front Ecol Environ 2016;14:325-32.

67. Torri SI, Corr^ea RS, Renella G. Soil carbon sequestration resulting from biosolids application. Appl Environ Soil Sci 2014;38:61-4.

68. Nannipieri P, Giagnoni L, Renella G, Puglisi E, Ceccanti B, Masciandaro G, et al. Soil enzymology: classical and molecular approaches. Biol Fert Soils 2012;48:743-62.

69. Shaheen S, Tsadilas C. Phosphorus sorption and availability to canola grown in an Alfisol amended with various soil amendments. Commun Soil Sci Plan 2013;4:89-103.

70. Stroup WW. Rethinking the analysis of non-normal data in plant and soil science. Agron J 2015;107(2):811-27.

71. Arianna Ci, Andrea GC. Properties and beneficial uses of (Bio)chars, with special attention to products from sewage sludge pyrolysis. Resources 2018;7:20.

72. Ugya AY, Tahir SM, Imam TS. Emerging trend in the remediation of pollution. 1st edition, Lambert Publishers, Balti, Moldova, 2016.

73. Torri SI, Alberti C. Characterization of organic compounds from biosolids of Buenos Aires City. J Soil Sci Plant Nutr 2012;12:143-52.

74. Yuan Z, Pratt S, Batstone DJ. Phosphorus recovery from wastewater through microbial processes. Curr Opin Biotechnol 2012;23:878-83.

75. White JW, Coale FJ, Sims JT, Shober AL. Phosphorus runoff from waste water treatment biosolids and poultry litter applied to agricultural soils. J Environ Qual 2010;39:314-23.

76. Alleoni LRF, Fernandes AR, Jord ao CB. Phosphorus availability in an Oxisol amended with biosolids in a longterm field experiment. Soil Sci Soc Am J 2012;76:1678-84.

77. Ugya AY, Tahir SM, Imam TS. The efficiency of Pistia stratiotes in the phytoremediation of Romi stream: a case study of Kaduna refinery and petrochemical company polluted stream. Int. J Health Sci Res 2015;5:492-7.

78. Anand K, Kumari B, Mallick MA. Phosphate solubilising microbes: an effective and alternative approach as biofertilizers. J Pharm Pharm Sci 2016;8:37-40.

79. Ugya AY. The efficiency of Lemna minor L. in the phytoremediation of Romi stream: a case study of Kaduna refinery and petrochemical company polluted stream. J Appl Biol Biotechnol 2015;3:11-4.

80. Athamenh BM, Salem NM, El-Zuraiqi SM, Suleiman W, Rusan MJ. Combined land application of treated wastewater and biosolids enhances crop production and soil fertility. Desalin Water Treat 2015;53:3283-94.

81. Ugya AY, Imam TS. The efficiency of Eicchornia crassipes in the phytoremediation of waste water from Kaduna Refinery and petrochemical company. IOSR J Environ Sci Toxicol Food Technol 2015;9:43-7.

82. Ahumada I, Sepúlveda K, Fernández P, Ascar L, Pedraza C, Richter P, et al. Effect of biosolid application to Mollisol Chilean soils on the bioavailability of heavy metals $(\mathrm{Cu}, \mathrm{Cr}, \mathrm{Ni}$, and $\mathrm{Zn})$ as assessed by bioassays with sunflower (Helianthus annuus) and DGT measurements. J Soil Sediment 2014;14:886-96.

83. Thangarajan R, Chowdhury S, Kunhikrishnan A, Bolan N. Interactions of soluble and solid organic amendments with priming effects induced by glucose. Vadose Zone J 2014;13(7):1-10.

84. Al-Dhumri S, Beshah FH, Porter NA, Meehan B, Wrigley R. An assessment of the guidelines in Victoria, Australia, for land application of biosolids based on plant-available nitrogen. Soil Res 2013;51:529-38.

85. Antunes E, Schumann J, Brodie G, Jacob MV, Schneider PA. Biochar produced from biosolids using a single-mode microwave: characterization and its potential for phosphorus removal. J Environ Manag 2017;196:119-26.
86. Pawlett M, Deeks LK, Sakrabani R. Nutrient potential of biosolids and urea derived organo-mineral fertilisers in a field scale experiment using ryegrass (Lolium perenne L.). Field Crops Res 2015;175:56-63.

87. Budarin VL, Shuttleworth PL, De bruyn M, Farmer TJ, Gronnow MJ, Pfaltzgraff L, et al. The potential of microwave technology for the recovery, synthesis and manufacturing of chemicals from bio-wastes. Catal Today 2015;239:80-9.

88. Lin Q, Chen G, Liu Y. Scale-up of microwave heating process for the production of biooil from sewage sludge. J Anal Appl Pyrolysis 2012;94:114-9.

89. Nanzer S, Oberson A, Berger L, Berset E, Hermann L, Frossard E. The plant availability of phosphorus from thermo-chemically treated sewage sludge ashes as studied by 33P labeling techniques. Plant and Soil 2014;377(1-2):439-56.

90. Agrafioti E, Bouras G, Kalderis D, Diamadopoulos E. Biochar production by sewage sludge pyrolysis. J Anal Appl Pyrolysis 2013;101:72-8.

91. Motasemi F, Afzal MT. A review on the microwave-assisted pyrolysis technique. Renew Sustain Energy Rev 2013;28:317-30.

92. Kelessidis A, Stasinakis AS. Comparative study of the methods used for treatment and final disposal of sewage sludge in European countries. Waste Manag 2012;32:1186-95.

93. Clarholm M, Skyllberg U, Rosling A. Organic acid induced release of nutrients from metalstabilized soil organic matter-the unbutton model. Soil Biol Biochem 2015;84:168-76.

94. Binkley D, Fisher RF. Ecology and management of forest soils. 4th edition, Wiley Blackwell, Chichester, UK, 2013.

95. Moro H, Kunito T, Sato T. Assessment of phosphorus bioavailability in cultivated Andisols from a longterm fertilization field experiment using chemical extractions and soil enzyme activities. Arch Agron Soil Sci 2015;61:1107-23.

96. Bøen A, Haraldsen TK, Krogstad T. Large differences in soil phosphorus solubility after the application of compost and biosolids at high rates. Acta Agr Scand B. 2013;63:473-82.

97. Antil RS, Bar-Tal A, Fine P, Hadas A. Predicting nitrogen and carbon mineralization of composted manure and sewage sludge in soil Compost Sci Util 2013;19:33-43.

98. Castillo MS, Sollenberger LE, Vendramini JMB, Woodard KR, O'Connor GA, Silveira ML, et al. Incorporation of municipal biosolids affects organic nitrogen mineralization and elephant grass biomass production. Agron J 2011;103(3):899-905.

99. Cooper J, Lombardi R, Boardman D, Carliell-Marquet C. The future distribution and production of global phosphate rock reserves. Resour Conserv Recy 2011;57:78-86.

100. Garcia FO, Kissel DE, Cabrera ML. Effect of soil matric potential on urea hydrolysis. Soil Sci Soc Am J 2014;78(6):2078-82.

101. Hui D, Mayes MA, Wang G. Kinetic parameters of phosphatase: a quantitative synthesis. Soil Biol Biochem 2015;65:105-13.

102. Johnson N. Fertilizer for the future. A phosphorus perspective. Nuffield Arden Scholarship 2011, UK, 2012.

103. Kirkby CA, Richardson AE, Wade LJ, Passioura JB, Batten GD, Blanchard C, et al. Nutrient availability limits carbon sequestration in arable soils. Soil Biol Biochem 2014;68:402-9.

104. Xu C, Weese JS, Flemming C, Odumeru J, Warriner K. Fate of Clostridium difficile during wastewater treatment and incidence in Southern Ontario watersheds. J Appl Microbiol 2014;117(3):891-904.

How to cite this article:

Ahmad AM, Ugya AY, Isah HA, Imam TS. Mineralization and mobilization of biosolids phosphorus in soil: A concise review. J Appl Biol Biotech 2019;7(05):98-106. 